\title{
REGENERASI KETERLIBATAN ANAK USIA SEKOLAH DALAM PENYALAHGUNAAN MIRAS DI DUSUN TIBU AMBUNG DESA LEMBAH SARI KECAMATAN BATU LAYAR
}

\author{
Riadi $^{1} \&$ Muhammad Isnaeni² \\ 1 Universitas Muhammadiyah Mataram, Mataram, Indonesia \\ 2 Universitas Muhammadiyah Mataram, Mataram, Indonesia \\ Email: riadisaepudin@yahoo.com
}

\begin{abstract}
Abstrak
Penelitian ini berupaya untuk mendeskripsikan masalah regenerasi keterlibatan anak-anak usia sekolah (7-21 tahun) dalam penyalahgunaan miras. Penyimpangan sosial dalam bentuk penyalahgunaan miras belakangan ini semakin marak dilakukan oleh anak-anak usia tersebut. Baik yang status sebagai siswa sekolah maupun tidak sekolah tapi dengan usia anak sekolah. Persoalan tersebut kaya akan problem akademik yang harus dicarikan formula untuk mengetahui latarbelakang dan solusinya. Selain penyakit bagi sekolah atau madrasah, penyakit pula bagi masyarakat tempat tinggal. Apabila hal tersebut tidak segera ditangani maka akan semakin akut. Lembah Sari adalah sebuah desa yang terletak di bawah kaki gunung, akan tetapi penyalahgunaan miras seperti kondisi di jantung kota. Anak-anak, remaja dan orang dewasa di desa ini rata-rata telah terkontaminasi minuman keras sehingga satu generasi dengan generasi yang lain saling mempengaruhi. Faktor-faktor yang menyebabkan regenerasi salah satunya kurangnya tingkat pendidikan, ekonomi lemah, kurangnya control orang tua, lingkungan tidak steril dan lain sebagainya. Penelitian ini dilaksanakan lima bulan, mulai dari penyusunan proposal, proses penelitian dan penyusunan laporan. Agar semuanya berjalan sesuia target maka penyusun telah menjadwalkan semua proses kegiatannya. Penelitian ini merupakan penelitian kualitatif yaitu sebuah prosedur penelitian yang menghasilkan data deskriptif berupa ucapan atau tulisan dan perilaku yang diamati dari orang-orang atau subyek itu sendiri. Supaya memperoleh data yang akuntabel dari proses yang dilakukan, penulis menggunakan teknik observasi dan wawancara untuk mengumpulkan data. Selanjutnya data yang telah terkumpul dianalisa dengan teknik analisis induktif.
\end{abstract}

Kata kunci: Regenerasi, Keterlibatan Anak Usia Sekolah, Miras.

\begin{abstract}
This study aims to describe the problem relating to school children and adult (around 7 to 21 years old) engagement in alcoholic drink. The research is a descriptive analysis which has been conducted around five months in Batu Layar District, West Lombok, West Nusa Tenggara. It is found that the factors caused their engagement in alcoholic drink are: their low level of education, economic weaknesses, lack of parent control, and environment that support them to close to alcoholic drink.
\end{abstract}

Keywords: Regeneration, school student engagement in alcohol 
Riadi \& Isnaeni, M. (2016). REGENERASI KETERLIBATAN ANAK USIA SEKOLAH DALAM PENYALAHGUNAAN MIRAS DI DUSUN TIBU AMBUNG DESA LEMBAH SARI KECAMATAN BATU LAYAR. JURNAL TATSQIF, 14(1), 103-120.

\section{PENDAHULUAN}

Dalam pandangan kontekstualis, sifat dasar manusia itu adalah suatu tindakan yang bukan hanya melibatkan tindakan itu saja, melainkan juga melibatkan orang yang bertindak dan orang yang berkaitan dengan orang yang bertindak tersebut. Singkatnya, menurut pandangan ini manusia hanya dapat dipahami dalam konteksnya. Manusia tidak independen, melainkan merupakan bagian dari lingkungannya (person-in-context). Manusia adalah individu yang aktif, organisme sosial dalam sistem yang luas dari kekuatan yang saling mempengaruhi masa lalu, masa kini dan masa yang akan datang. Tingkah anak terjadi dalam konteks tingkah laku orang lain. Anak secara aktif mencari dan merespon berbagai konteks sosial dan fisik (Desmita: 2012:31).

Seiring terjadinya pergeseran corak hidup dari agraris ke industrialis, sifat dasar manusia tersebut setidaknya terformat dengan gaya industrialis yang selalu diiringi dengan nilai positif dan nilai negatif (plus-minus). Nilai positif bagi mereka yang mampu menghadapi tantangan industrialis dengan menyiapkan diri sebaik mungkin sedangkan nilai negatif bagi mereka yang 'lari' dari persaingan dan cenderung mengisolasi diri dari perubahankemajuan. Akibatnya banyak dari mereka yang prustasi dengan sengaja melanggar norma masyarakat dan norma agama dengan alibi mencari jati diri. Bahkan pelaku penyimpangan sosial tersebut dengan sengaja menempuh cara-cara persuasif agar perbuatannya dinilai menarik dan diikuti oleh orang-orang sekitarnya. Menurut Sarlito W. Sarwono sebagaimana dikutip Sahilun A. Nasir (2002) menjelaskan bahwa jumlah manusia muda yang begitu besar bisa berarti keuntungan sekaligus kerugian bagi bangsa Indonesia yang sedang membangun ini. Ia merupakan keuntungan jika dapat dimanfaatkan seoptimal mungkin untuk kepentingan pembangunan, akan tetapi kerugianlah yang akan terjadi jika justru menjadi beban dan tanggungan bagi anggota masyarakat lainnya.

Salah satu penyimpangan sosial yang sering dilakukan adalah penyalahgunaan miras. Seolah tanpa mengenal sekat miras menjadi bagian 
Riadi \& Isnaeni, M. (2016). REGENERASI KETERLIBATAN ANAK USIA SEKOLAH DALAM PENYALAHGUNAAN MIRAS DI DUSUN TIBU AMBUNG DESA LEMBAH SARI KECAMATAN BATU LAYAR. JURNAL TATSQIF, 14(1), 103-120.

negatif masyarakat yang tidak bisa dilepaskan. Kekuatan negatif miras mampu menembus batas kota bahkan ke pelosok-pelosok desa. Parahnya, penyalahgunaan miras dilakukan secara 'berjamaah', turun temurun antar generasi dari dewasa, remaja bahkan sampai usia anak-anak.

Prosesi re-generasi berlangsung secara pelan tapi pasti menjangkiti masyarakat setempat. Kartini Kartono (2008:3) menjelaskan bahwa gangguan masa remaja dan anak-anak yang disebut sebagai childhood disorders dan menimbulkan penderitaan emosional minor serta gangguan kejiwaan lain pada pelakunya, dikemudian hari bisa berkembang menjadi bentuk kejahatan remaja (juvenile delinquency). Kejahatan yang dilakukan oleh anak-anak muda remaja pada intinya merupakan produk dari kondisi masyarakatnya dengan segala pergolakan sosial yang ada di dalamnya. Kejahatan anak remaja ini disebut sebagai salah satu penyakit masyarakat atau penyakit sosial. Lebih lanjut dijelaskan oleh Kartini Kartono, penyakit sosial atau penyakit masyarakat adalah segala bentuk tingkah laku yang dianggap tidak sesuai, melanggar norma-norma umum, adat-istiadat, hukum formal, atau tidak bisa diintegrasikan dalam pola tingkah laku umum. Disebut sebagai penyakit masyarakat karena gejala sosialnya yang terjadi di tengahtengah masyarakat itu meletus menjadi penyakit. Disebut pula sebagai struktur sosial yang terganggu fungsinya (disfungsi) disebabkan oleh factorfaktor sosial.

Anak usia sekolah adalah anak dengan rentang usia antara 7-21 tahun atau anak usia sekolah dengan jenjang pendidikan SD/MI, SMP/MTs dan SMA/MA. Rentang usia tersebut sesuai dengan teori tertua tentang fase-fase perkembangan yang membagi fase-fase itu atas 7 tahun, sehingga dari masa kanak-kanak sampai dewasa terbagi atas tiga septennial yaitu rentang usia 07 tahun disebut masa kanak-kanak, usia 7-14 tahun disebut masa sekolah dan usia 14-21 tahun disebut masa pubertas (Agus Sujanto, 1998: 238). Masing-masing usia tersebut menurut Elizabeth B. Hurlock memiliki masamasa labil misalnya bahaya usia anak, usia remaja dan usia dewasa. 
Riadi \& Isnaeni, M. (2016). REGENERASI KETERLIBATAN ANAK USIA SEKOLAH DALAM PENYALAHGUNAAN MIRAS DI DUSUN TIBU AMBUNG DESA LEMBAH SARI KECAMATAN BATU LAYAR. JURNAL TATSQIF, 14(1), 103-120.

Penyakit masyarakat ini semakin mengkhawatirkan bukan hanya terjadinya re-generasi dari usia dewasa, remaja dan anak, akan tetapi juga diantaranya terlibat anak-anak usia sekolah dengan angka yang cukup signifikan. Kekhawatiran ini sangat beralasan mengingat anak usia sekolah akan kehilangan masa depan sejak dini. Dampak individual dan sosial yang diakibatkan miras mampu merusak tatanan sistem kemasyarakatan karena dampak ikutan dari miras ini menimbulkan berbagai penyimpangan lainnya seperti perjudian, pelacuran, kriminalitas dan sejenisnya.

Lokus penelitian ini akan dilakukan di desa Lembah Sari dengan beberapa alasan diantaranya tingginya tingkat keterlibatan anak usia sekolah dalam penyalahgunaan minuman keras, tingginya angka putus sekolah, tingginya angka pengangguran, tidak adanya jenjang pendidikan orang tua, tingginya dampak penyimpangan sosial yang terjadi akibat minuman keras dan tidak adanya sosialisasi tentang bahaya miras.

Terhadap pelaku penyalahgunaan miras, upaya regresif pernah dilakukan di desa Lembah Sari akan tetapi hal tersebut tidak efektif bahkan semakin hari jumlahnya semakin bertambah. Dugaan penulis cara yang dilakukan masih kurang tepat, justru menimbulkan perlawanan dan kebencian. Upaya-upaya sejenis tidak pernah lagi dilakukan oleh para tokoh masyarakat akan tetapi sebaliknya justru upaya re-generasi semakin menunjukkan bentuknya. Jumlah keterlibatan anak usia sekolah semakin bertambah dan sangat menghawatirkan.

Menurut Robert D. Wirt dan Peter F Briggs mengatakan deliquensi remaja tidak saja meningkat jenis jumlahnya, tetapi juga meningkat jenis perbuatannya. Baik yang berupa social delinquency maupun individual delinquency. Kenakalan yang dilakukan oleh remaja tersebut adalah menjurus ke arah perbuatan yang bersifat negatif dan destruktif, bahkan juga bersifat kriminal, sehingga membawa dampak negatif yang sangat merugikan masyarakat, nusa dan bangsa (Sahilun A. Nasir, 2002:7).

Berdasarkan pada informasi masyarakat dan studi awal yang dilakukan 
Riadi \& Isnaeni, M. (2016). REGENERASI KETERLIBATAN ANAK USIA SEKOLAH DALAM PENYALAHGUNAAN MIRAS DI DUSUN TIBU AMBUNG DESA LEMBAH SARI KECAMATAN BATU LAYAR. JURNAL TATSQIF, 14(1), 103-120.

peneliti bahwa pada umumnya di desa Lembah Sari dan pada khususnya di dusun Sidemen Daye-Tibu Ambung memiliki tingkat penyalahgunaan miras yang cukup tinggi sehingga potensial terjadinya re-generasi yang melibatkan anak usia sekolah. Berdasarkan dengan hal tersebut, penelitian ini akan mengkaji secara mendalam tentang Regenerasi Keterlibatan Anak Usia Sekolah dalam Penyalahgunaan Miras di Dusun Tibu Ambung Desa Lembah Sari Kecamatan Batu Layar.

Berdasarkan latar belakang di atas, maka penulis dapat merumuskan masalah pokok yang menjadi fokus kajian sebagai berikut: 1) Bagaimana pola regenerasi Keterlibatan Anak Usia Sekolah dalam Penyalahgunaan Miras di Dusun Tibu Ambung Desa Lembah Sari Kecamatan Batu Layar?; 2) Apa factor-faktor yang melatarbelakangi keterlibatan anak usia sekolah dalam penyalahgunaan miras di dusun Tibu Ambung desa Lembah Sari?; 3) Apa upaya-upaya yang dilakukan dalam mencegah keterlibatan anak usia sekolah dalam keterlibatannya dalam penyalahgunaan miras di dusun Tibu Ambung desa Lembah Sari?

\section{METODE}

Jenis penelitian ini berupa penelitian analisis deskriptif kualitatif, seperti yang diungkapkan oleh Lexy Moleong bahwa penelitian jenis kualitatif adalah penelitian yang bermaksud untuk memahami fenomena tentang apa yang dialami oleh subjek penelitian misalnya perilaku, persepsi, motivasi, tindakan dan lain-lain secara holistic, dan dengan cara deskripsi dalam bentuk kata-kata dan bahasa, pada suatu konteks khusus yang alamiah dan dengan memanfaatkan berbagai metode alamiah (Lexy Moleong, 2008; 6). Dari jenis penelitian yang digunakan diharapkan dapat mendeskripsikan rumusan masalah yang diangkat oleh penulis, yang mengambil locus penelitian di desa Lembah Sari khususnya di dusun Tibu Ambung. Dengan demikian, penelitian ini menjelaskan dan menggambarkan bagaimana pola re-generasi pelaku penyimpangan sosial. 
Riadi \& Isnaeni, M. (2016). REGENERASI KETERLIBATAN ANAK USIA SEKOLAH DALAM PENYALAHGUNAAN MIRAS DI DUSUN TIBU AMBUNG DESA LEMBAH SARI KECAMATAN BATU LAYAR. JURNAL TATSQIF, 14(1), 103-120.

Penelitian ini mengambil locus di desa Lembah Sari Kecamatan Batu Layar tepatnya di dusun Sidemen Daye dan Tibu Ambung. Desa Lembah Sari menjadi locus penelitian dengan pertimbangan bahwa desa ini merupakan tempat tinggal peneliti sehingga lebih mudah bagi penulis melakukan interview dengan para informan (interviewee). Letak desa ini strategis dan mudah dijangkau dari jalan utama. tingginya angka pengangguran, anak putus sekolah, anak usia sekolah dengan ketergantungan minuman keras.

Untuk memperoleh data yang sesuai dengan yang dibutuhkan penulis dalam penelitian ini, maka dalam penelitian ini digunakan metode pengumpulan data yang sesuai dengan metode pengumpulan data jenis penelitian kualitatif yaitu menggunakan metode wawancara, observasi dan dokumentasi dan triangulasi.

Metode analisa yang digunakan adalah analisis induktif yaitu suatu proses pemahaman yang didasarkan pada informasi atau data dan fakta dari lapangan dan kemudian mencoba mensintesiskannya ke dalam beberapa kategori atau mencocokkannya dengan teori yang ada (M. Toha Anggoro, dkk, 2007: 6.18). Dengan demikian, data yang terhimpun dibahas, ditafsirkan dan terkumpul secara induktif sehingga memberikan gambaran yang jelas mengenai hal-hal yang terjadi.

\section{HASIL DAN PEMBAHASAN}

\section{Setting Tempat Penelitian}

Secara geografis, desa Lembah Sari terletak di kecamatan Batu Layar kabupaten Lombok Barat. Sejarah awal desa Lembah Sari ini merupakan pemekaran dari desa Kekait. Lembah Sari memiliki enam dusun dari arah selatan ke utara secara berurutan yakni dusun Lendang Re, dusun Lembah Sari, dusun Sidemen Lauq, dusun Eat Gereneng, dusun Sidemen Daye dan dusun Tibu Ambung. Jumlah penduduk desa Lembah Sari berjumlah 2.830 jiwa terdiri dari 1. 408 laki dan 1.422 perempuan (Dokumentasi, 1 Maret 2015). 
Riadi \& Isnaeni, M. (2016). REGENERASI KETERLIBATAN ANAK USIA SEKOLAH DALAM PENYALAHGUNAAN MIRAS DI DUSUN TIBU AMBUNG DESA LEMBAH SARI KECAMATAN BATU LAYAR. JURNAL TATSQIF, 14(1), 103-120.

Dari jumlah keseluruhan penduduk desa Lembah Sari tersebut, dusun Tibu Ambung memiliki 310 kepala keluarga dengan jumlah penduduk keseluruhan 654 jiwa (Dokumentasi, 3 Maret 2015). Jumlah penduduk dusun Tibu Ambung tersebut, bila diklasifikasikan menurut jenjang pendidikan, sebagian besar hanya lulusan sekolah dasar dan hanya beberapa orang saja yang lulus SMA/MA dan PT. Untuk lebih jelasnya, terkait klasifikasi masyarakat dusun Tibu Ambung berdasarkan jenjang pendidikan sebagai berikut:

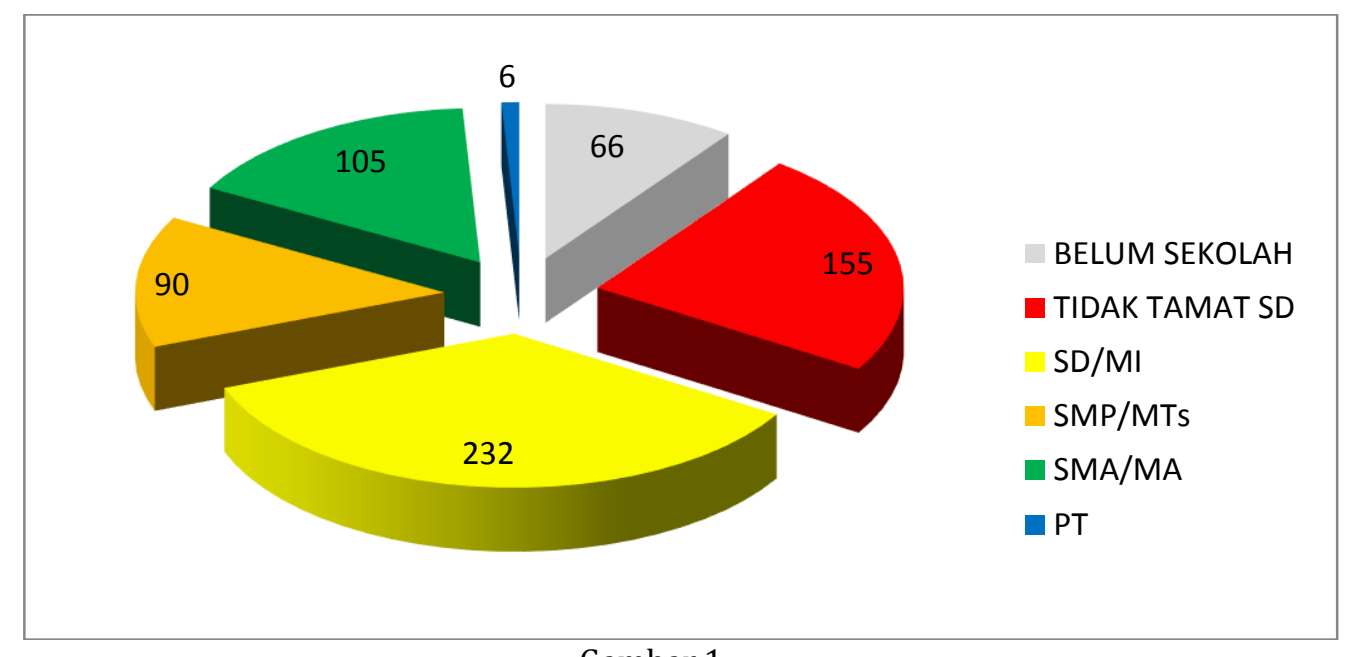

Gambar 1

Masyarakat Tibu Ambung Berdasarkan Jenjang Pendidikan

Dari data di atas menunjukkan tingkat pendidikan masyarakat dusun Tibu Ambung memprihatinkan dan sangat mengkhawatirkan. Keprihatinan dan kekhawatiran tersebut bisa terjadi karena tidak adanya estapet keteladanan dalam kehidupan sehari-hari. Meskipun jenjang pendidikan tidak selalu berbanding lurus dalam pola hidup sehari-hari (dalam arti rendah jenjang pendidikan maka rendah pula moral masyarakatnya dan sebaliknya). Namun pendidikan tetap diyakini mampu menjadi alat perubahan, sehingga bila dilihat dari data di atas maka kekurangcerdasan dan kemunduran moral sampai mengantarkan pada prilaku penyimpangan sosial sangat-sangat mungkin terjadi. 
Riadi \& Isnaeni, M. (2016). REGENERASI KETERLIBATAN ANAK USIA SEKOLAH DALAM PENYALAHGUNAAN MIRAS DI DUSUN TIBU AMBUNG DESA LEMBAH SARI KECAMATAN BATU LAYAR. JURNAL TATSQIF, 14(1), 103-120.

\section{Regenerasi Keterlibatan Anak Usia Sekolah dalam Penyalahgunaan Miras} di dusun Tibu Ambung Desa Lembah Sari

Regenerasi yang dimaksud adalah bentuk penggantian generasi tua kepada generasi muda atau biasa disebut peremajaan. Sejalan dengan alur kehidupan bermasyarakat sesungguhnya ada semacam pewarisan nilai-nilai sosial yang terus dilakukan, bersifat turun-temurun dari generasi ke generasi. Regenerasi merupakan suatu keniscayaan dalam setiap masyarakat. Pewarisan nilai sosial bukan hanya dilakukan oleh orang-orang tertentu dengan nilai-nilai tertentu, namun pewarisan nilai sosial bisa saja dilakukan oleh sembarang orang (tanpa melihat status) dan nilai apa yang akan diwarisi pada saat terjadinya interaksi sosial.

Dalam interaksi sosialnya, individu bereaksi membentuk pola sikap tertentu terhadap berbagai objek psikologis yang dihadapinya. Diantara berbagai faktor yang mempengaruhi pembentukan sikap adalah pengalaman pribadi, kebudayaan, orang lain yang dianggap penting, media massa, institusi atau lembaga pendidikan dan lembaga agama, serta faktor emosi dalam diri individu (Saifuddin Azwar, 2011:20).

Mengacu pada data masyarakat berdasarkan jenjang pendidikan di atas (gambar 1), bila dilihat dari kenyataan sosial yang ada terdapat banyak sekali anggota masyarakat yang melakukan penyimpangan sosial. Bahkan pelaku penyimpangan sosial di dusun tersebut melibatkan anakanak usia sekolah. Jenis penyimpangan sosial yang dilakukan berupa penyalahgunaan minuman keras (berbagai jenis dan merk) dan kebiasaan tersebut cenderung diikuti dengan penyimpanganpenyimpangan sosial lainnya.

Pelaku minuman keras dengan berbagai latar belakang status dan pendidikan di dusun Tibu Ambung berjumlah delapan puluh empat (84) orang, sebagian besar dari jumlah tersebut didominasi oleh anak usia sekolah. Untuk lebih jelasnya dapat dilihat pada tabel berikut: 
Riadi \& Isnaeni, M. (2016). REGENERASI KETERLIBATAN ANAK USIA SEKOLAH DALAM PENYALAHGUNAAN MIRAS DI DUSUN TIBU AMBUNG DESA LEMBAH SARI KECAMATAN BATU LAYAR. JURNAL TATSQIF, 14(1), 103-120.

Tabel 1

Data Keterlibatan Anak Usia Sekolah dalam Penyalahgunaan Miras

\begin{tabular}{|c|l|c|l|}
\hline No & Jenjang Pendidikan & Jml/orang & Keterangan \\
\hline 1 & Usia SD/MI & - & \\
\hline 2 & Usia SMP/MTs & 42 orang & \\
\hline 3 & Usia SMA/MA & 25 orang & \\
\hline 4 & Usia PT & 17 orang & 11 orang sudah menikah \\
\hline
\end{tabular}

Dari data keterlibatan anak sekolah di atas dengan mengkaji jumlah penduduk dengan membanding jumlah keterlibatan anak usia sekolah dalam penyalahgunaan minuman keras menunjukkan bahwa angka keterlibatan anak sekolah sangat tinggi. Bahkan potensial angka tersebut dari hari ke hari dan dari generasi ke generasi akan semakin meningkat. Potensi tersebut tidak akan terjadi begitu saja (tanpa sebab) akan tetapi banyak faktor pemicu (trigger) yang mempengaruhi.

Angka yang sangat tinggi tersebut pada awalnya terjadi karena adanya kontak dengan lingkungan luar, sebagaimana dijelaskan oleh $\mathrm{H}$. Ridwan kadus Tibu Ambung bahwa sekitar tahun 1990-2000an beberapa remaja (pada saat itu) bekerja di salah satu gudang meuble di daerah Ampenan. Sekembalinya dari Ampenan mereka memiliki banyak teman baru yang seiring waktu berjalan mereka tetap menjalin pertemanan musti mereka sudah berhenti bekerja (Wawancara H. Ridwan dan Mardan, 5 Maret 2015). Salah satu dari mereka (Z) menjelaskan bahwa hasil dari pergaulan tersebut banyak dari teman-teman tersebut yang mengenal berbagai macam minuman keras dan itu berlanjut sampai sekarang (Wawancara, Z, 5 Maret 2015). Dari penjelasan informan di atas, awalnya secara individual mereka bukan individu-individu yang mengenal-suka minuman keras akan tetapi lebih dipengaruhi oleh adanya faktor luar yang sangat situasional sehingga perilaku dan kebiasaan mereka menjadi berubah drastis. Generasi awal pelaku penyimpangan sosial dipengaruhi oleh lingkungan luar. 
Riadi \& Isnaeni, M. (2016). REGENERASI KETERLIBATAN ANAK USIA SEKOLAH DALAM PENYALAHGUNAAN MIRAS DI DUSUN TIBU AMBUNG DESA LEMBAH SARI KECAMATAN BATU LAYAR. JURNAL TATSQIF, 14(1), 103-120.

Berdasarkan temuan data tentang pelaku minuman keras di dusun Tibu Ambung, secara alami telah terjadi regenerasi pewarisan nilai sosial yang buruk dari generasi tua ke generasi muda bahkan melibatkan anakanak. Sebagaimana dijelaskan oleh H. Ridwan kadus Tibu Ambung bahwa pelaku minuman keras di dusun ini semakin hari semakin bertambah bahkan yang sangat mengkhawatirkan adanya keterlibatan anak yang masih sekolah (Wawancara, H. Ridwan, 3 Maret 2015). Pada saat bersamaan H. Syukriadi salah satu tokoh agama juga menyesalkan dengan tingginya angka pemabuk di dusun ini, lebih lanjut dijelaskan bahwa para pemabuk ini telah ketergantungan dengan minuman keras sehingga memicu hilangnya semangat bekerja bagi yang tidak sekolah dan hilangnya semangat belajar bagi yang masih sekolah (Wawancara, $\mathrm{H}$. Syukriadi, 3 Maret 2015). Data yang diperoleh menunjukkan pelaku dengan usia bekerja/kuliah sebanyak 17 orang, usia SMA/MA sebanyak 25 orang, usia SMP/MTs sebanyak 42 orang. Untuk lebih jelasnya berikut gambaran pelaku minuman keras di dusun Tibu Ambung:

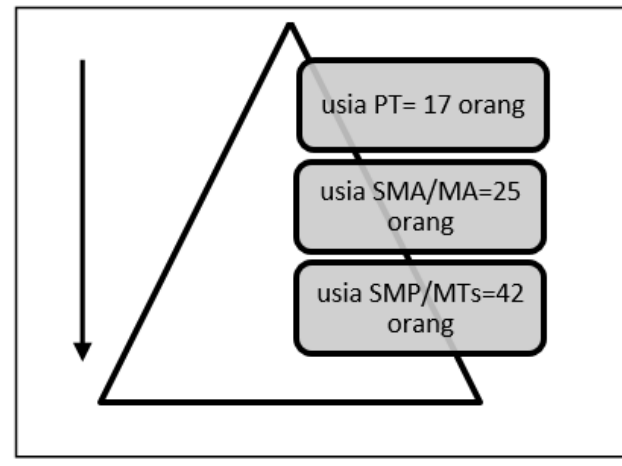

Gambar 2

Piramida Jumlah Pelaku Minuman Keras

Angka yang sangat tinggi dengan komposisi antar usia ini tentu memiliki alasan-alasan penyimpangan tersebut terjadi. Dari hasil observasi penulis, alasan terjadinya regenerasi penyimpangan sosial di dusun Tibu Ambung pertama pola pergaulan yang salah, kedua pemanggilan dengan gelar buruk, ketiga keterbukaan pergaulan antara 
Riadi \& Isnaeni, M. (2016). REGENERASI KETERLIBATAN ANAK USIA SEKOLAH DALAM PENYALAHGUNAAN MIRAS DI DUSUN TIBU AMBUNG DESA LEMBAH SARI KECAMATAN BATU LAYAR. JURNAL TATSQIF, 14(1), 103-120.

dewasa dan anak-anak, dan keempat Dusun Tibu Ambung tidak memiliki awik-awik.

a. Pergaulan yang salah

Tingginya angka penyimpangan sosial lintas generasi ini terjadi diawali dari pergaulan yang salah. Pergaulan yang terjadi adalah percampuran pergaulan lintas usia antara anak-anak dengan orang yang dewasa. Anak-anak lebih memilih bergaul dengan orang dewasa sedangkan orang dewasa tidak memberikan teladan yang baik terhadap anak-anak. Salah yang dimaksud adalah ketidakmampuan individu dalam menseleksi teman sepergaulan dan tidak mampu memilah baik-buruknya nilai dan norma di tengah masyarakat.

b. Pemanggilan dengan Gelar Buruk/Pemberian gelar dengan nama yang buruk

Mudahnya terjadi regenerasi penyimpangan sosial di dusun Tibu Ambung selain dikarenakan pergaulan, juga didukung dengan pemanggilan dengan gelar yang buruk baik oleh anak-anak ke orang dewasa maupun sebaliknya. Tidak ada sanksi bagi pelaku pemanggilan tersebut sehingga pemanggilan dengan gelar buruk tersebut dianggap biasa. Gelar-gelar buruk tersebut biasanya teraspirasi dari nama-nama binatang atau gelar-gelar pelaku asusila.

c. Keterbukaan Pergaulan Antara Dewasa-Anak

Pergaulan yang diterapkan tidak membatasi antara orang dewasa dengan anak-anak. Akhirnya proses dan hasil pergaulan dewasa dengan anak-anak sama tanpa terkecuali, sehingga anakanak yang tidak cukup umur akan mudah melakukan anomali di tengah masyarakat.

d. Tidak Adanya Awik-Awik Dusun

Dusun Tibu Ambung termasuk dusun yang sangat bebas karena dusun ini termasuk dusun yang tidak memiliki awik-awik yang 
Riadi \& Isnaeni, M. (2016). REGENERASI KETERLIBATAN ANAK USIA SEKOLAH DALAM PENYALAHGUNAAN MIRAS DI DUSUN TIBU AMBUNG DESA LEMBAH SARI KECAMATAN BATU LAYAR. JURNAL TATSQIF, 14(1), 103-120.

dijadikan pedoman bermasyarakat. Karenanya berbagai anomali yang dilakukan baik disengaja maupun yang tidak diharapkan banyak terjadi di kalangan remaja. Melihat kenyataan yang ada, dapat ditarik kesimpulan bahwa berbagai penyimpangan yang terjadi di dusun tersebut diperkuat dengan tidak adanya awik-awik yang membatasi antara perbuatan yang baik dengan perbuatan yang buruk.

\section{Faktor-Faktor Yang Melatarbelakangi Keterlibatan Anak Usia Sekolah} Menjadi Pelaku Minuman Keras

Setiap penyimpangan sosial pastinya berawal dari hal-hal yang 'sepele' dan bergelinding menjadi semakin 'gede'. Pelakunya pun biasanya berawal dari usia remaja sampai dewasa. Keterlibatan banyaknya pelaku penyimpangan dari penyimpangan yang 'sepele' sampai 'gede' pasti memiliki alasan tertentu. Terbukti bahwa pelakupelaku minuman keras di dusun Tibu Ambung mengenal minuman keras sejak usia sekolah (Dokumentasi, 10 Maret 20150. Kebiasaan tersebut terbawa sampai mereka menginjak usia dewasa bahkan sampai berumah tangga.

Beberapa alasan keterlibatannya meliputi faktor yang berasal dari dalam dan luar dari diri pelaku. Faktor-faktor yang melatarbelakangi keterlibatan anak usia sekolah menjadi pelaku minuman keras di dusun Tibu Ambung adalah pertama, kurangnya kontrol orangtua, kedua kurangnya tingkat pendidikan orangtua dan masyarakat dan ketiga faktor lingkungan.

a. Kurangnya kontrol orangtua

Anak dalam rentang perjalanan kehidupannya pada usia sekolah (sejak lahir sampai SMA sederajat) masih sangat membutuhkan bimbingan orang-orang sekitarnya terutama orangtua. Kontrol orangtua sangat menentukan arah perkembangan setiap anak. Bila anak mendapat pengawasan yang ketat sekaligus 
Riadi \& Isnaeni, M. (2016). REGENERASI KETERLIBATAN ANAK USIA SEKOLAH DALAM PENYALAHGUNAAN MIRAS DI DUSUN TIBU AMBUNG DESA LEMBAH SARI KECAMATAN BATU LAYAR. JURNAL TATSQIF, 14(1), 103-120.

diarahkan ke arah yang positif maka anak akan menjadi baik, akan tetapi sebaliknya bila anak lepas dari kontrol orangtua maka anak akan kehilangan arah dan cenderung mengikuti hal-hal negatif yang terjadi di sekitarnya. Dalam sebuah wawancara dijelaskan oleh Mardan ketua RT 2 bahwa faktor-faktor yang melatarbelakangi hal tersebut terjadi karena kurangnya kesadaran diri dan kontrol orangtua (Wawancara, Mardan, 3 Maret 2015). Untuk membuktikan keterangan dari RT tersebut, penulis mengamati anak-anak sekolah tersebut ternyata persis apa yang disampaikan oleh RT di atas bahwa kebiasaan anak-anak sekolah tersebut setelah pulang dari sekolahnya masing-masing mereka mencair dengan teman-teman yang notabene lebih dewasa, bahkan mereka lebih memilih nongkrong di Bengkel atau di tempat-tempat yang biasanya dijadikan tempat minum.

Dengan mengutip QS. Ar-Rum: 30 dan hadits, Ahmad Janan Asifudin menyimpulkan bahwa setiap manusia menurut fitrah, kodrat dan pembawaannya cenderung kepada kebaikan. Yakni menyukai kebaikan, keindahan, kebenaran, keadilan dan sebagainya. Artinya bahwa manusia memiliki pembawaan tidak menyukai keburukan, kejahatan, kesalahan, ketidakadilan dan sejenisnya. Namun pengaruh orangtua (mewakili lingkungan berupa pergaulan, bacaan, pendidikan dan lain-lain yang bernilai negatif), manusia bisa menjadi buruk, jahat dan seterusnya (Ahmad Janan Asifuddin, 2009:47).

Dari penjelasan di atas, kesalahan awal yang terjadi pada pelaku penyimpangan sosial usia sekolah di dusun Tibu Ambung adalah lingkungan yang tidak steril dalam bentuk lepasnya kontrol orang tua.

b. Kurangnya tingkat pendidikan orangtua dan masyarakat

Tingginya angka pelaku penyimpangan sosial usia sekolah juga 
Riadi \& Isnaeni, M. (2016). REGENERASI KETERLIBATAN ANAK USIA SEKOLAH DALAM PENYALAHGUNAAN MIRAS DI DUSUN TIBU AMBUNG DESA LEMBAH SARI KECAMATAN BATU LAYAR. JURNAL TATSQIF, 14(1), 103-120.

dipengaruhi oleh rendahnya tingkat pendidikan orangtua dan masyarakat. Faktor ini sepertinya menjadi faktor yang mendasari faktor pertama yakni kurangnya kontrol orangtua. Orangtua yang berpendidikan memiliki tingkat perhatian yang berbeda dengan orangtua yang tidak berpendidikan. Data yang diperoleh di dusun Tibu Ambung menunjukkan hanya beberapa masyarakat saja yang memiliki pendidikan dan masyarakat yang berpendidikan tersebut tidak satupun termasuk orangtua dari pelaku minuman keras.

c. Faktor lingkungan

Tingginya angka keterlibatan anak usia sekolah menjadi pelaku penyimpangan sosial di dusun Tibu Ambung tentunya dipengaruhi oleh banyak faktor. Selain faktor-faktor yang disebutkan di atas, faktor lingkungan juga turut menyumbang angka penyimpangan sosial. Dari data yang didapat di atas menunjukkan bahwa lingkungan dusun Tibu Ambung darurat miras, pada waktu yang bersamaan tidak ada upaya antisipasi dan pencegahan yang dilakukan oleh para tokoh masyarakat (Observasi, 13 Maret 2015). Dalam kesempatan berbeda, Mardan ketua RT menjelaskan bahwa masyarakat terlalu sibuk dengan urusan kebutuhan sehari-hari, para orangtua dalam rangka memenuhi kebutuhannya mereka pergi pagi pulang sore hari sehingga sangat sedikit sekali waktu untuk memantau perkembangan anak mereka masing-masing (Wawancara, Mardan, 15 Maret 2015).

Lingkungan termasuk di dalamnya para orangtua memiliki peran penentu atas perkembangan seorang anak. Dalam Islam lingkungan ini mendapat perhatian yang sangat serius, hal tersebut menunjukkan lingkungan memiliki daya dalam proses pembentukan karakter anak. 
Riadi \& Isnaeni, M. (2016). REGENERASI KETERLIBATAN ANAK USIA SEKOLAH DALAM PENYALAHGUNAAN MIRAS DI DUSUN TIBU AMBUNG DESA LEMBAH SARI KECAMATAN BATU LAYAR. JURNAL TATSQIF, 14(1), 103-120.

4. Upaya-Upaya Yang Dilakukan dalam Mencegah Keterlibatan Anak Usia Sekolah Menjadi Pelaku Minuman Keras

Penyimpangan sosial dalam konteks 'miras' ini merupakan pelanggaran norma agama dan norma sosial. Artinya, setiap masyarakat yang menjadi pelaku minuman keras secara otomatis melanggar norma agama dan pelakunya mendapat dosa, selain itu pelaku minuman keras juga melanggar norma sosial karena melakukan pelanggaran kesepakatan masyarakat. Bahkan melanggar norma yang kedua ini memiliki sanksi yang lebih nyata dan berat karena sanksinya dirasakan langsung oleh pelaku sesuai dengan berat-ringannya pelanggaran yang dilakukan.

Data pelaku minuman keras di dusun Tibu Ambung sangat tinggi dan didukung oleh lingkungan yang tidak steril bagi dunia anak di bawah pengawasan orangtua, akan tetapi sudah menjadi hukum alam bahwa setiap penciptaan itu pasti berpasang-pasangan seperti baik-buruk, lakiperempuan dan seterusnya. Demikian juga di dusun Tibu Ambung, di balik kenyataan suram tersebut terselip pula harapan perbaikan dari para tokoh. Harapan tersebut termanipestasi dalam bentuk upaya yang dilakukan oleh para tokoh masyarakat.

Salah satu upaya yang pernah dilakukan oleh tokoh masyarakat sebagai upaya mencegah bertambahnya angka keterlibatan masyarakat 'berkenalan' dengan miras adalah men-sanksi para pelaku minuman keras. Adapun inisiator dari upaya tersebut adalah H. Faozan. Dalam beberapa kesempatan, H. Faozan (Wawancara, 25 Maret 2015) menjelaskan langkah pertama yang dilakukan adalah mendatangi para orangtua pelaku minuman keras, memberikan permakluman bahwa apa yang dilakukan oleh anak-anak mereka adalah tidak sesuai dengan Islam. Pada kesempatan itu pula diberikan pandangan terhadap dampak yang akan terjadi pada anak dan lingkungan. Hasil pertemuan tersebut, sebagaimana yang penulis saksikan langsung bahwa selang beberapa 
Riadi \& Isnaeni, M. (2016). REGENERASI KETERLIBATAN ANAK USIA SEKOLAH DALAM PENYALAHGUNAAN MIRAS DI DUSUN TIBU AMBUNG DESA LEMBAH SARI KECAMATAN BATU LAYAR. JURNAL TATSQIF, 14(1), 103-120.

hari dari pertemuan dengan masing-masing orangtua tersebut, H. Faozan bersama para orangtua tersebut mengumpulkan para pelaku minuman keras di rumahnya Bapak Mustajap. Setelah semua pelaku minuman keras tersebut terkumpul, H. Faozan sebagai inisiator langsung memukul semua pelaku sampai berdarah-darah. Upaya tersebut mengundang berbagai polemic baik yang setuju maupun yang tidak setuju. Menurut Kartini Kartono, pola yang dipilih dalam rangka upaya pencegahan bertambahnya pelaku minuman keras tersebut ternyata belakangan ini dapat disimpulkan bahwa cara yang diterapkan adalah cara yang salahfatal. Menurut Kartini Kartono tindakan hukuman bagi anak remaja deliquen antara lain berupa: menghukum mereka sesuai dengan perbuatannya, sehingga dianggap adil dan bisa menggugah berfungsinya hati nurani sendiri untuk hidup susila dan mandiri.

Upaya yang dilakukan tersebut lebih mengarah pada cara-cara regresif sehingga melahirkan perlawanan dari para pelaku dan melahirkan keberatan-keberatan dari orangtua masing-masing. Pasca kejadian tersebut bukannya mengurangi jumlah pelaku minuman keras justru semakin menumbuhkan jiwa 'perlawanan' dari masing-masing mereka. Terbukti banyak dari mereka belakangan ini tidak suka terhadap tokoh-tokoh yang dianggap terlibat dalam 'pembelajaran' saat itu.

Untuk mencegah meningkatnya angka keterlibatan anak usia sekolah maka penting dilakukan tindakan-tindakan yang bersifat preventif. Tindakan-tindakan yang dapat dilakukan diantaranya: 1) peningkatan kesejahteraan keluarga, 2) perbaikan lingkungan, 3) mendirikan klinik bimbingan psikologis dan edukatif untuk memperbaiki tingkah laku dan membantu remaja dari kesulitan mereka, 4) menyediakan tempat rekreasi yang sehat bagi remaja, 5) membentuk badan kesejahteraan anak-anak, 6) mengadakan panti asuhan, 7) membuat badan supervise dan pengontrol terhadap kegiatan anak 
Riadi \& Isnaeni, M. (2016). REGENERASI KETERLIBATAN ANAK USIA SEKOLAH DALAM PENYALAHGUNAAN MIRAS DI DUSUN TIBU AMBUNG DESA LEMBAH SARI KECAMATAN BATU LAYAR. JURNAL TATSQIF, 14(1), 103-120.

deliquen disertai program yang korektif, 9) menyusun undang-undang khusus untuk pelanggaran dan kejahatan yang dilakukan oleh anak dan remaja, 11) mendirikan sekolah bagi anak gembel dan 12) mendirikan tempat latihan untuk menyalurkan kreatifitas para remaja deliquen dan yang non deliquen.

Dari beberapa alternatif tindakan preventif di atas tentunya tidak semua sesuai dengan kultur tempat tinggal, namun demikian semua itu tetap penting dengan memilih-memilah yang relevan dengan pelaku dan tempat tinggal pelaku.

\section{KESIMPULAN}

Berdasarkan uraian, analisa dan pembahasan di atas tentang pola regenerasi penyimpangan sosial, dapat disimpulkan sebagai berikut:

1. Pola regenerasi pelaku penyimpangan sosial di dusun Tibu Ambung awalnya terjadi karena adanya kontak dengan dunia luar (faktor eksternal). Generasi awal ini selanjutnya mempengaruhi generasigenerasi muda berikutnya bahkan melibatkan anak-anak usia sekolah. Mudahnya terjadi regenerasi pelaku penyimpangan sosial di dusun Tibu Ambung karena pertama Pergaulan yang salah, kedua Pemanggilan/pemberian gelar dengan nama yang buruk, ketiga Tidak Adanya Awik-Awik Dusun yang bersifat mengikat.

2. Faktor yang melatarbelakangi keterlibatan anak usia sekolah menjadi pelaku minuman keras di dusun Tibu Ambung adalah kurangnya kontrol orangtua, kurangnya tingkat pendidikan orangtua dan masyarakat, faktor lingkungan. Tidak adanya konsistensi para anak sekolah terhadap statusnya sebagai anak sekolah dengan apa yang dilakukan sewaktu di rumah atau lingkungan.

3. Upaya-upaya yang pernah dilakukan di dusun Tibu Ambung dengan memberikan sanksi terhadap para pelaku. Upaya ini termasuk sebagai upaya regresif yang menyisakan 'luka' terhadap para pelaku. Para pelaku 
Riadi \& Isnaeni, M. (2016). REGENERASI KETERLIBATAN ANAK USIA SEKOLAH DALAM PENYALAHGUNAAN MIRAS DI DUSUN TIBU AMBUNG DESA LEMBAH SARI KECAMATAN BATU LAYAR. JURNAL TATSQIF, 14(1), 103-120.

merasa keberatan dan tidak terima terhadap cara yang telah dilakukan oleh para tokoh agama dan tokoh masyarakat. Sampai saat ini para tokoh belum pernah melakukan upaya-upaya yang sifatnya preventif untuk mencegah meningkatnya angka keterlibatan anak sekolah sebagai pelaku minuman keras.

\section{DAFTAR PUSTAKA}

A. Nasir, Sahilun, Peranan Pendidikan Agama terhadap Pemecahan Problem Remaja, Jakarta: Kalam Mulia, 2002.

B. Hurlock, Elizabeth, Psikologi Perkembangan Suatu Pendekatan Sepanjang Rentang Kehidupan, Jakarta: Erlangga.

Bungin, Burhan, Metodologi Penelitian Kualitatif Aktualisasi Metodologis Ke Arah Ragam Variam Kontemporer, Jakarta: Raja Grafindo Persada. 2006.

Desmita, Psikologi Perkembangan, Bandung: Remaja Rosdakarya, 2012.

Desmita,. Psikologi Perkembangan Peseta Didik Panduan Bagi Orant Tua dan Guru dalam Memahami Psikologi Anak Usia SD, SMP dan SMA, Bandung: Rosdakarya, 2012.

Kamus Lengkap Bahasa Indonesia, Tim Prima Pena, Gita Media Press.

Kartono, Kartini, Patologi Sosial, Jakarta: Rajawalipers, 2007.

Kartono, Kartini, Kenakalan Remaja, Jakarta: Rajawali Pers, 2008.

Moleong, Lexy, Metodologi Penelitian Kualitatif, Bandung: Remaja Rosdakarya, 2008.

Priyatno, Yatim, Metodologi Penelitian Pendidikan, Surabaya: SIC, 2001.

Sujanto, Agus, Psikologi Perkembangan, Jakarta: Rineka Cipta, 1998.

Supardi. Metodologi Penelitian, Mataram: Yayasan Cerdas Press, 2006.

Toha Anggoro, M. dkk,. Metode Penelitian, Jakarta: Universitas Terbuka, 2007.

W. Sarwono, Sarlito, , Psikologi Remaja, Jakarta: Rajawali Pers, 2011. 